\title{
Tourism and rural development: policy analysis and lessons from the LEADER method
}

\author{
Juan Gabriel Tirado Ballesteros ${ }^{1}$
}

Received: 08/03/2018

\begin{abstract}
1 Universidad de Alicante. University Institute for Tourism Research. Address: Carretera de San Vicente del Raspeig, s/n, 03690 Sant Vicent del Raspeig, Alicante, Spain. Phone: +34 9659037 26. E-mail: gabriel.tirado@ua.es
\end{abstract}

Supervisor: María Hernández Hernández

Institution awarding the Ph. D. Degree: University of Alicante (Spain)

Date of defence: 22/09/2017

(C) 2018 Varna University of Management. All rights reserved

Citation: Tirado-Ballesteros, J.G. (2018) Tourism and rural development: policy analysis and lessons from the LEADER method. Doctoral Dissertation Summary. European Journal of Tourism Research 20, pp. 125-128

\section{Goal and objectives of the dissertation Goal}

The main objective of this $\mathrm{PhD}$ thesis is to provide a sectoral perspective of the implementation of the EU Rural Development Programs (RDP) and to have a better understanding of the relationship between tourism and rural development through the implementation of the LEADER method.

\section{Objectives}

This thesis brings an operational, tactical and sectoral assessment of the implementation of EU RDP. To reach this point and in order to meet the main goal, the following objectives were set:

$\checkmark$ Objective 1. To analyse the background of rural development policies and articulation of programmes through the LEADER approach.

$\checkmark$ Objective 2. To examine the methodological tools proposed by the EU

DOCTORAL DISSERTATION for measuring the impact of RDP, from LEADER I to the 2007-13 RDP.

$\checkmark$ Objective 3. To identify the key factors affecting the competitiveness of destinations in rural areas from a holistic perspective.

$\checkmark$ Objective 4. To analyse the result of the functionality of tourism projects developed through the implementation of RDP in some case study in Spain.

$\checkmark$ Objective 5 . To conduct an in-depth study concerning pull factors of rural tourism destination in some case study in Spain.

$\checkmark$ Objective 6. To study the key elements in the relationship between rural development governance and the tourism projects accomplished.

$\checkmark$ Objective 7. To promote capacity building through examples of good practice in the implementation of LEADER method and tourism. 


\section{Methodology}

This thesis used an integrated approach in which quantitative methods (statistical analysis of the socio-economic impacts resulting from the implementation of EU RDP) are combined with qualitative methodologies (interviews and questionnaires to rural development managers, entrepreneurs, public sector representatives, tourism specialists and scholars). In relation to the methodological issues of the empirical focus of the doctoral thesis, the study was structured into three parts. In the first part, in order to assess the efficiency of investments in the tourism sector through initiatives and programs based on the LEADER approach, a categorisation of over 4,200 tourism project from the 1990s to the present was carried out. Information were transcribed and managed with Microsoft Excel, the mappings included were developed using QGIS software.

In a second part, a structured survey with open-ended questions was chosen as the method to explore the challenges regarding pull factors of destinations located in rural areas. It addressed quantitative and qualitative pull factors in relation to improving the competitiveness of rural tourism destinations. The survey was sent to key stakeholders ( $\mathrm{N}=118)$ : a) researchers; b) entrepreneurs and representatives of rural tourism associations; c) rural development managers and d) public administration tourism staff.

Finally, in the third part, a qualitative approach was also used. Semi-structured interviews $(\mathrm{N}=9)$ were conducted to understand the key issues in rural development governance and its influence in the development of tourism activities. For this purpose, managers and Local Action Group (LAG) staff were interviewed. Processing of the information collected was done using qualitative analysis software Atlas.ti.

\section{Results}

The categorisation and study of tourism projects has made it possible to understand the role of tourism in the distribution of the investment made through the EU RDP. The oversupply of accommodation is one of the main dysfunctionalities observed, the design and structuring of destination products is an aspect that also needs to be reviewed. After reading the tourism projects developed over the last 25 years, the application of the LEADER method is questionable, there are few tourism packages developed at the local level that promote public-private partnerships and articulate resources of a similar type at the supramunicipal level.

Similarly, the participation of the population and the integration of agricultural activities into the configuration of destination products should be strengthened (Esparcia, 2000). The shift in policy orientation has left many farmers unable to adapt to the new scenario. Very few venture to design, plan and market tourism products linked to their agricultural, livestock or agri-food activities. The lack of integration of tourism with agricultural activities in the cases analysed reveals the gap between rural development and agriculture (Hernández, 2008).

\section{Theoretical conclusions}

Regarding the theoretical conclusions, the study carried out on the evolution of the Common Agricultural Policy (CAP) has given rise to a greater understanding of the inclusion of tourism as a driving force for rural development (Barke, 2004; Haven-Tang \& Jones, 2012). Similarly, this analysis has helped to explain the proposed EU RDP methodologies and also the synergies that could be derived from applying the LEADER method (Chevalier \& Dedeire, 2014).

The fact that the processes related to the design, management and forms of organisation of EU Regulations and Guidelines for rural development can be transferred to the academic realm also represents a remarkable contribution. Given the orientation of the doctoral thesis, an indepth knowledge of the assessment processes is particularly important. The conclusions obtained as a result of the analysis of the methods for evaluating tourism have opened new lines of research in the field of study. 


\section{Practical application of the dissertation}

The diachronic study of the evolution of the CAP has allowed a better understanding of the conflicts between farmers and LAG stakeholders. This circumstance confirms the need for a greater cohesion of policies aimed at the diversification of agriculture.

The findings also highlight that most of the weaknesses and opportunities identified in rural destinations are linked to governance. Public-private partnership, coordination on both horizontal and vertical level, participation of the population and the integration of agricultural activities should be strengthened. In this respect, it is appropriate to emphasise the importance of the rural development organizations established within the LEADER approach.

DMOs should steer towards similar structures to those proposed by the EU via the LEADER. A tool for management, planning and stimulus such as the LAG, at least in theory, precisely addresses the weaknesses identified in this doctoral thesis. In practice, these structures lack legitimacy and have insufficient rallying power for the public authorities to relegate leadership in the intervention of tourism policy (Pulido \& Cardenas, 2011).

\section{Content of the dissertation}

\section{Abstract of Chapter 1}

The first chapter is the introduction of the doctoral thesis. The justification of the research and the relevance of the project are discussed. The research framework, objectives, methods and case study are then presented.

\section{Abstract of Chapter 2}

In order to guide the theoretical foundations of the doctoral thesis, Chapter 2 examines the origins and evolution of agricultural policies that have favoured the development of tourism activities in rural areas. Similarly, a diachronic study of the CAP was carried out and the associated decoupling of agricultural subsidies in favour of new approaches to rural development.

\begin{abstract}
Chapter 3
Chapter 3 analyses the methodologies proposed for evaluating EU RDP and tourism projects. The literature review reveals that the mandatory evaluation systems used pay insufficient attention to analysing the impact of these programmes on the territory and few studies have assessed the impact of tourism generated by RDP.
\end{abstract}

\section{Abstract of Chapter 4 \\ The theoretical framework was complemented with a holistic analysis of the pull and push factors affecting the competitiveness of rural tourism destinations. This analysis has also been useful to clarify the functionality of the RDP and their influence on the different elements that make up the internal and external tourist systems.}

\section{Abstract of Chapter 5}

In this chapter, tourism projects through EU RDP from LEADER I (1991-1994) to RDP 2007-2013 were analysed. From a pragmatic perspective, a diachronic reading of the volume of investment in tourism and a classification of tourism projects developed were carried out. These data were applied to the case study of Valencia and Castilla-La Mancha (Spain).

\section{Abstract of Chapter 6}

In Chapter 6, a more detailed description of the factors influencing the location of tourist activities in rural areas was conducted. More specifically, this was done from the perspective of supply and with an exploratory purpose, so weaknesses and areas for improvement in the key elements were identified in rural destinations by means of a tourism-related stakeholders survey also applied to the case study of Valencia and Castilla-La Mancha (Spain).

\section{Abstract of Chapter 7 \\ Chapter 7 focused on clarifying the causes for dysfunctions in LAG management and the implementation of LEADER method. Tourism planning processes, the degree of decentralisation and participation in decision- making, the criteria established for project eligibility, social responsibility, transparency}


or communication were some of the most important aspects analysed at this chapter.

\section{Abstract of Chapter 8}

In Chapter 8, several examples of good practices applied on tourism projects were exposed by way of preliminary findings. Paradigmatic examples of structuring, design and implementation of LEADER method were described in order to foster a demonstration effect.

\section{Abstract of Chapter 9}

This chapter reviews the key findings of the doctoral thesis. The main theoretical, practical and methodological contributions to the research field are also discussed in this chapter. Likewise, the limitations encountered in the development of this thesis are presented, as well as some guidelines for future lines of research.

\section{References:}

Barke, M. (2004). Rural tourism in Spain. International Journal of Tourism Research, 6(3), 137-149

Chevalier, P., \& Dedeire, M. (2014). Application du programme LEADER selon les principes de base du développement local. Économie rurale, (4), 9-25

Esparcia, J. (2000). The LEADER programme and the rise of rural development in Spain. Sociologia Ruralis, 40(2), 200-207

Haven-Tang, C., \& Jones, E. (2012). Local leadership for rural tourism development: A case study of Adventa, Monmouthshire, UK. Tourism Management Perspectives, 4, 28-35

Hernández, M. (2008). Balance de las políticas de desarrollo rural en la Comunidad Valenciana (1991-2006). Investigaciones Geográficas, 45, 93-119

Pulido, J. I., \& Cardenas, P. J. (2011). El turismo rural en España: orientaciones estratégicas para una tipología aún en desarrollo. Boletín de la Asociación de Geógrafos Españoles, (56), 155-17 